\title{
Statistical analysis in enrichment of total whey protein by continuous foam fractionation method
}

\author{
Goutam Mukhopadhyaya,*, Jasmina Khanamb , Arunabha Nandab, \\ Nripendra Nath Balaa and Won Chun Ohc \\ a Bengal Chemists and Druggists Association, College of Pharmacy and Technology, Kolkata-127, 700127, India \\ b Department of Pharmaceutical Technology, Jadavpur University, Kolkata-32, 700032, India \\ c Department of Advance Material Science and Engineering, Hanseo University, Seosansi, Chungnam-356-706, Korea
}

${ }^{*}$ Corresponding author at: Bengal Chemists and Druggists Association, College of Pharmacy and Technology, Kolkata-127, 700127, India. Tel.: +91.33.25842665; fax: +91.33.2584433. E-mail address: goutam bst@yahoo.com (G. Mukhopadhyay).

\section{ARTICLE INFORMATION}

Received: 05 July 2011

Received in revised form: 10 August 2011

Accepted: 14 August 2011

Online: 31 December 2011

\section{KEYWORDS}

\section{Box-Behnken design}

Optimization

Foam separation

Whey

Enrichment ratio

Separation ration

\section{Introduction}

Whey protein is a rich source of essential amino acid [1]. In the cheese industry, whey is produced as a byproduct containing substantial amount of proteins that are either added to dairy products or animal fodder or are discharged as waste, resulting in high Bacteriological Desiccators (BOD) [2,3]. Its importance was extensively realized by the industrialists and whey proteins had been recovered from whey by different methods. It is the renewed interest of scientists to improve the quality of product coupled with efficiency of cost [4]. Whey proteins impart some functional advantages such as enhancement of solubility, viscosity, gel forming capacity, foaming ability etc. to food products [5]. Functionality of whey proteins is influence by a number of compositional factors, physicochemical factors such as composition of proteins, temperature, $\mathrm{pH}$, ionic strength, concentration of $\mathrm{Ca}^{2+}$ and other ions, molecules. Solubility of whey proteins vary in isoelectric $\mathrm{pH}$ (IEP) range, heat induced state [6]. Proteinsurfactant complex show different hydrophobicity at a $\mathrm{pH}$ other than IEP and at IEP. Whey protein concentrate had been reported to have poor foaming stability, emulsifying ability at low concentration. So, foaming of whey is assisted by the surface active agents in foam fractionation experiment of separation to maximize enrichment [7]. The separation of proteins from a culture medium or whey is usually carried out by adsorption, ion exchange, chromatography and various membrane separation methods [8-10]. Foam fractionation in adsorptive bubble separation method offers several advantages over these methods e.g. ease of scale up, flexibility in continuous operation, very high separation efficiency and cost effectiveness [11]. So far, some investigators reported their works with pure concentrate and characterized the separation experiment ratio, \% recovery of product, selectivity and separation ratio. Selective separation of protein from a multicomponent system was also made possible partially if there is wide gap in their isoelectric $\mathrm{pH}$ [12].

In the present work, processed native whey has been chosen to study separation by continuous foam fractionation and its optimization by the Response surface methodology. In the past decades, many have used RSM in food process design for the optimization of variables owing to the ease of operation, reliability and reproducibility of the model parameters as well as the availability of uses friendly computer software packages [13-14]. The Response Surface Methodology (RSM) encompasses the use of experimental design, generation of polynomial equation, mapping of the responses over the experimental domain to determine optimum conditions to achieve desired responses [15]. Investigators get advantages by saving time in running of numerous experiments in order to achieve optimization when compared to conventional empirical method. RSM is more effective and precise if experiments are suitably designed. In this paper, we report application of RSM in the foam fractionation of native whey (waste) to study the role of $\mathrm{pH}\left(\mathrm{X}_{1}\right)$, Gas flow rate of Nitrogen gas (GFR, $\mathrm{X}_{2}$ ) and Protein Surfactant Ratio (PSR, $\mathrm{X}_{3}$ ) and Volumetric Flow rate (VFR, $\mathrm{X}_{4}$ ) different response variables such as concentration of Foamate, concentration of residual feed solution, enrichment 


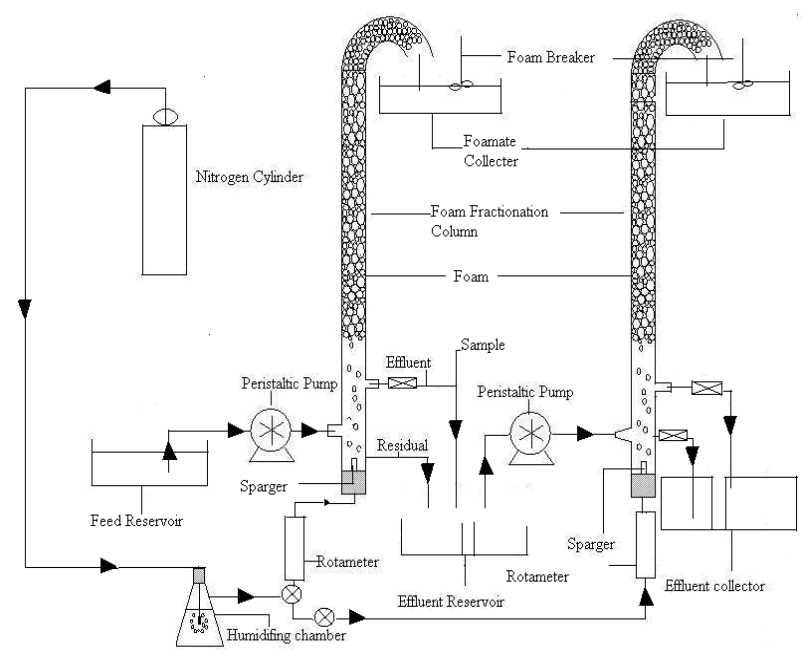

Figure 1. Foam fractionation apparatus operating in continuous mode.

ratio, percentage recovery, using Box-Behnken design. The model generates regression equations and response surface plots that correlate independent and dependent variables with these optimizes values, maximum \% recovery can be achieved easily.

\section{Experimental}

\subsection{Experimental design}

The experimental design and analysis of date were performed with the help of design-expert (Version 7.1.7. StatEase, Minneapolis, USA) [16]. Factorial design based on multiple regression analysis involved the main, the quadratic and interactive effects that were caused by four independent operating variables. These variables generated few response variables. The four studied parameters were $\mathrm{pH}$ of feed solution (whey), Gas flow rate (GFR), Protein-Surfactant ratio (PSR) and Volumetric flow rate (VFR). Response variables were concentration of protein in foamate $\left(\mathrm{C}_{\mathrm{f}}\right)$, enrichment ratio of protein $\left(\mathrm{Er}=\mathrm{C}_{\mathrm{f}} / \mathrm{C}_{\mathrm{r}}\right)$, and percentage recovery of protein $\left(\% \mathrm{R}_{\mathrm{p}}\right)$. Following is the general model for response surface,

$Y=b o+\sum_{i=1}^{i=3} b_{i} x_{j}+\sum_{i=1}^{i=3} b_{i j} x^{2}{ }_{i j}+\sum_{i<j=2}^{i=3} b_{i j} x_{i} x_{j}+e \ldots \ldots \ldots \ldots$.

The Box-Behnken design was used for the optimization of all variables. ANOVA was performed with the coefficients related to block term, linear, quadratic and interactive terms. The model generated second order polynomials for different responses [17]. Table 1 represents levels of design parameters that were treated for experimental design.

Table 1. The levels of variables chosen for the trials at fixed $(\mathrm{Ci}=500$ $\mu \mathrm{g} / \mathrm{mL})$.

\begin{tabular}{llll}
\hline Level/Factor & $\mathbf{- 1}$ & $\mathbf{0}$ & $\mathbf{+ 1}$ \\
\hline $\mathrm{X}_{1}, \mathrm{pH}$ & 2 & 5 & 8 \\
$\mathrm{X}_{2}, \mathrm{GFR}\left(\mathrm{cm}^{3} / \mathrm{min}\right)$ & 250 & 290 & 330 \\
$\mathrm{X}_{3}, \mathrm{PSR}$ & 1.25 & 1.5 & 1.75 \\
$\mathrm{X}_{4}, \mathrm{VFR}\left(\mathrm{cm}^{3} / \mathrm{min}\right)$ & 12 & 14 & 16 \\
\hline $\mathrm{X}_{1}, \mathrm{X}_{2}, \mathrm{X}_{3}$ and $\mathrm{X}_{4}$ are variables of model equation had been exhibited as in two
\end{tabular}

$\mathrm{X}_{1}, \mathrm{X}_{2}, \mathrm{X}_{3}$ and $\mathrm{X}_{4}$ are variables of model equation had been exhibited as in two dimensional contour plots and three dimensional response surface plots.

\subsection{Materials, instruments, equipment}

Whey was supplied by local confectionery; sodium dodecyl sulfate (SDS) was obtained from Loba (India). Double distilled water was prepared at laboratory. The instruments used were
UV spectrophotometer (UV 1700 Shimadzu), pH meter (Satorius), Centrifuge (Remi), Foam fractionation apparatus was supplied by local glass fabricator.

\subsection{Quantification of whey protein}

The protein fraction is determined by spectrophotometric analysis at wavelength $280 \mathrm{~nm}$. The standard curve is prepared by whey protein powder and that is prepared by evaporating aqueous part of solvent from treated whey under controlled condition in a BOD.

\subsection{Treatment of whey}

Raw and fresh whey is collected from local confectionery. It is filtered through cheesecloth. The filtrate is centrifuged and filtered several times until absorbance becomes constant at wavelength of $280 \mathrm{~nm}$. Thus fat is removed. Fat has detrimental effect on foaming property. Film rigidity decreases when fat competes with protein molecules. It is then diluted as per requirement and concentration is checked by spectrophotometer [18].

\subsection{Foam fractionation}

The experimental set up (Figure 1) consists of a glass column, nitrogen cylinder, humidifier (glass set), air flow meter, foam receiver and stirrer. The glass column is designed and fabricated by local fabricator. It is of 1 meter length having an internal diameter of $8 \mathrm{~cm}$. A porous glass sparger (Frit no. 3, pore size 16-40 micron) is fitted on the top of a small glass tube and that is attached at the bottom of column by standard joint. Feed was prepared by suitable dilution of stock whey to get the desired feed concentration. Required quantity of Sodium Lauryl Sulphate (SLS) was added to the feed to get the desired PSR, it was then allowed to mix uniformly with the help of an ultrasonic cleaner. Then the $\mathrm{pH}$ of the feed was measured and adjusted as per requirement. The foam fractionation column was then filled with $1 \mathrm{~L}$ of feed solution and Nitrogen gas was passed through the feed at desired gas flow rate (GFR). Feed was introduced from outside through an inlet in the column with the help of a peristaltic pump to maintain a constant volumetric flow rate, and the effluent is constantly collected through a outlet from other side, the flow rate of the outgoing 
Table 2. Experimental design of variables.

\begin{tabular}{|c|c|c|c|c|c|c|c|c|}
\hline Std & Run & $\mathrm{pH}$ & GFR & PSR & VFR & Cf & Er & $\% \mathrm{Rp}$ \\
\hline 24 & 1 & 0.00 & 1.00 & 0.00 & 1.00 & 6715.85 & 13.43 & 81.69 \\
\hline 10 & 2 & 1.00 & 0.00 & 0.00 & -1.00 & 5905.13 & 11.81 & 69.88 \\
\hline 3 & 3 & -1.00 & 1.00 & 0.00 & 0.00 & 5602.62 & 11.20 & 70.35 \\
\hline 15 & 4 & 0.00 & -1.00 & 1.00 & 0.00 & 8014.76 & 16.02 & 85.15 \\
\hline 14 & 5 & 0.00 & 1.00 & -1.00 & 0.00 & 5340.00 & 10.68 & 75.85 \\
\hline 25 & 6 & 0.00 & 0.00 & 0.00 & 0.00 & 8872.94 & 17.74 & 94.27 \\
\hline 5 & 7 & 0.00 & 0.00 & -1.00 & -1.00 & 6908.34 & 13.81 & 81.76 \\
\hline 22 & 8 & 0.00 & 1.00 & 0.00 & -1.00 & 7599.25 & 15.19 & 89.94 \\
\hline 4 & 9 & 1.00 & 1.00 & 0.00 & 0.00 & 5549.60 & 11.09 & 78.82 \\
\hline 8 & 10 & 0.00 & 0.00 & 1.00 & 1.00 & 6861.10 & 13.72 & 83.46 \\
\hline 16 & 11 & 0.00 & 1.00 & 1.00 & 0.00 & 6323.52 & 1.64 & 89.82 \\
\hline 9 & 12 & -1.00 & 0.00 & 0.00 & -1.00 & 5834.55 & 11.66 & 69.05 \\
\hline 21 & 13 & 0.00 & -1.00 & 0.00 & -1.00 & 7194.97 & 14.38 & 85.15 \\
\hline 6 & 14 & 0.00 & 0.00 & 1.00 & -1.00 & 7354.33 & 14.70 & 87.04 \\
\hline 2 & 15 & 1.00 & -1.00 & 0.00 & 0.00 & 6856.04 & 13.71 & 72.84 \\
\hline 20 & 16 & 1.00 & 0.00 & 1.00 & 0.00 & 5519.17 & 11.03 & 75.88 \\
\hline 18 & 17 & 1.00 & 0.00 & -1.00 & 0.00 & 5281.16 & 10.56 & 72.61 \\
\hline 13 & 18 & 0.00 & -1.00 & -1.00 & 0.00 & 6693.05 & 13.38 & 71.11 \\
\hline 7 & 19 & 0.00 & 0.00 & -1.00 & 1.00 & 7081.95 & 14.16 & 86.15 \\
\hline 23 & 20 & 0.00 & -1.00 & 0.00 & 1.00 & 7112.03 & 14.22 & 86.51 \\
\hline 17 & 21 & -1.00 & 0.00 & -1.00 & 0.00 & 5929.41 & 11.85 & 74.45 \\
\hline 1 & 22 & -1.00 & -1.00 & 0.00 & 0.00 & 6181.27 & 12.36 & 77.61 \\
\hline 26 & 23 & 0.00 & 0.00 & 0.00 & 0.00 & 8872.94 & 17.74 & 94.27 \\
\hline 19 & 24 & -1.00 & 0.00 & 1.00 & 0.00 & 5143.14 & 10.23 & 70.71 \\
\hline 12 & 25 & 1.00 & 0.00 & 0.00 & 1.00 & 5381.53 & 10.76 & 65.46 \\
\hline 11 & 26 & -1.00 & 0.00 & 0.00 & 1.00 & 6210.42 & 12.42 & 75.54 \\
\hline 27 & 27 & 0.00 & 0.00 & 0.00 & 0.00 & 8872.94 & 17.74 & 94.27 \\
\hline
\end{tabular}

effluent is same as the incoming feed. Bubbles are formed initially which then rises to the top of the column leading to formation of foam. The foam is continuously collected for required period of time. Foam was then allowed to stir using a stirrer until the foam breaks down to form foamate.

The effluent was collected in a reservoir, the residual was also collected, then the collected material (effluent) was pumped into the second column, where it acts as feed for the second column. When the work with the first column is finished the gas flow into the first column was stopped and the valve is opened so that the gas now flows into the second column and samples were withdrawn at regular intervals assessed. After steady state was achieved, the effluent showed constant concentration. Whole procedure is repeated again as mentioned above. The volume of foamate is measured, suitably diluted and absorbance is noted. The total effluent and residual was collected and absorbance was noted, the total input amount, output amount, loss amount, recovery \%, enrichment ratio were also calculated. Samples are analyzed by spectrophotometer. Data are presented in Table 2 as the average of experimental results.

\section{Results and discussion}

Table 1 represents levels of design parameters that were treated for experimental design. Operating variables used in the experiments, $\mathrm{pH}, \mathrm{GFR}, \mathrm{PSR}, \mathrm{VFR}$ were presented in coded form, responses variables $\left(\mathrm{C}_{\mathrm{f}}, \mathrm{E}_{\mathrm{r}}\right.$, and $\left.\% \mathrm{R}_{\mathrm{p}}\right)$ were calculated and tabulated in Table 3. These values were used to run the software within the chosen levels of parameters response variables have ranges that were presented along with mean values and standard deviation in Table 3 .

Table 3. Response variables from experimental date along with standard deviation.

\begin{tabular}{llll}
\hline Response Variables & Range of all runs & Mean & S.D. \\
\hline$C_{\mathrm{f}}$ & $5143.14-8928.24$ & 6647.32 & 1.1202 \\
$\mathrm{E}_{\mathrm{r}}$ & $10.23-17.85$ & 13.2737 & 2.23985 \\
$\% \mathrm{R}_{\mathrm{p}}$ & $65.41-89.94$ & 78.0252 & 7.88249 \\
\hline
\end{tabular}

\subsection{Concentration $\left(C_{f}\right)$ of protein in foamate solution}

It is expressed by the following model equation.
$\mathrm{Y}_{1}=8872.94-34.06 \mathrm{~A}-410.06 \mathrm{~B}+165.18 \mathrm{C}-119.47 \mathrm{D}-$

$181.95 \mathrm{AB}+256.07 \mathrm{AC}-224.87 \mathrm{AD}-84.55 \mathrm{BC}-200.11 \mathrm{BD}-$

166.71CD -2120.26A2 - 896.65B2 - 1238.28C2 - 774.59 $\mathrm{D}^{2}$

The above quadratic model was written from the values obtained from Table 4 . It showed $\mathrm{R}^{2}$ value as 0.9041 . This implies $2.23 \%$ of the total variation could not be explained by the model whereas the model was found significant $(\mathrm{p}=0.0004)$. There is only $0.04 \%$ chance of error in 'Model Fvalue' that could occur due to noise. The model had been presented after eliminating non-significant parameters ( $\mathrm{p}>$ 0.05). Model exhibited the effect of main parameters A and B. There was negative regression coefficient in the quadratic effect of $B$ (GFR). At centre value of B, highest response was obtained. Response $\left(\mathrm{Y}_{1}\right)$ decreased at $\mathrm{pH}$ other than isoelectric point (IEP). At IEP, protein becomes slightly hydrophobic and adsorbs more at the interface [19]. The model was adequate because of its high $\mathrm{R}^{2}$ value. In this model regression coefficient of A was found greatest in comparison to other factors. Effect of gas flow rate (GFR) was observed very much prominent. The model was free of the effects of interactions between factors as since it had insignificant $p$-value. It is inferred that $\mathrm{C}_{\mathrm{f}}$ was influenced significantly by the increased of $\mathrm{pH}$ and GFR. Response surface plots revel factor-response interactions as do model regression equation. Figure 2 showed two-dimensional iso-response curves. Response $\mathrm{Y}_{1}$ increased with the increased of $\mathrm{C}_{\mathrm{i}}$ and maximized when $\mathrm{pH}$ approached 5 . Figure 3 revealed similar three-dimensional surface effect of A (pH) and B (GFR) on the response variable $\mathrm{Y}_{1}\left(\mathrm{C}_{\mathrm{f}}\right)$.

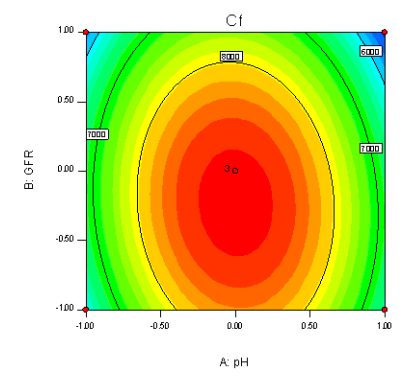

Figure 2. Two dimensional isoresponse curve of foamate (Cf). 
Table 4. Regression coefficients and their $\mathrm{p}$-values for the linear regression model for predicting optimized responses $\left(\mathrm{C}_{\mathrm{f}}, \mathrm{E}_{\mathrm{r}}\right.$ and $\left.\% \mathrm{R}_{\mathrm{p}}\right)$.

\begin{tabular}{|c|c|c|c|c|c|c|c|c|}
\hline \multicolumn{3}{|c|}{$\mathrm{C}_{\mathrm{f}}\left(\mathrm{Y}_{1}\right)$} & \multicolumn{3}{|c|}{$E_{r}\left(Y_{2}\right)$} & \multicolumn{3}{|c|}{$\% \mathrm{Rp}\left(\mathrm{Y}_{3}\right)$} \\
\hline Factor & b-coefficient & p-value & Factor & b-coefficient & p-value & Factor & b-coefficient & p-value \\
\hline Intercept & 8872.94 & 0.0004 & Intercept & 17.74 & 0.0004 & Intercept & 94.27 & 0.0046 \\
\hline $\mathrm{A}-(\mathrm{pH})$ & -34.06 & 0.8201 & $\mathrm{~A}-(\mathrm{pH})$ & -0.63 & 0.8328 & $\mathrm{~A}-(\mathrm{pH})$ & -0.18 & 0.8974 \\
\hline $\mathrm{B}-(\mathrm{GFR})$ & -410.11 & 0.0161 & $\mathrm{~B}-(\mathrm{GFR})$ & -0.82 & 0.0162 & B-GFR) & 0.68 & 0.6395 \\
\hline C-(PSR) & 165.18 & 0.2817 & C-(PSR) & 0.32 & 0.2899 & C-(PSR) & 2.51 & 0.0991 \\
\hline D-(VFR) & -119.47 & 0.4308 & D-(VFR) & -0.24 & 0.4358 & D-(VFR) & -0.33 & 0.8160 \\
\hline $\mathrm{AB}$ & -181.95 & 0.4872 & $\mathrm{AB}$ & -0.37 & 0.4866 & $\mathrm{AB}$ & 3.31 & 0.1986 \\
\hline AC & 256.07 & 0.3330 & AC & 0.52 & 0.3244 & $\mathrm{AC}$ & 1.75 & 0.4851 \\
\hline $\mathrm{AD}$ & -224.87 & 0.3931 & $\mathrm{AD}$ & -0.45 & 0.3910 & $\mathrm{AD}$ & -2.73 & 0.2842 \\
\hline $\mathrm{BC}$ & -84.55 & 0.7448 & $\mathrm{BC}$ & -0.17 & 0.7439 & $\mathrm{BC}$ & -0.018 & 0.9944 \\
\hline $\mathrm{BD}$ & -200.11 & 0.4458 & $\mathrm{BD}$ & -0.40 & 0.4467 & $\mathrm{BD}$ & -2.40 & 0.3429 \\
\hline CD & -166.71 & 0.5237 & $\mathrm{CD}$ & -0.33 & 0.5255 & $\mathrm{CD}$ & -1.99 & 0.4287 \\
\hline$A^{2}$ & -2120.26 & $<0.0001$ & $\mathrm{~A}^{2}$ & -4.24 & $<0.0001$ & $\mathrm{~A}^{2}$ & -16.19 & $<0.0001$ \\
\hline $\mathrm{B}^{2}$ & -896.65 & 0.0015 & $\mathrm{~B}^{2}$ & -1.79 & 0.0016 & $\mathrm{~B}^{2}$ & -4.73 & 0.0443 \\
\hline $\mathrm{C}^{2}$ & -1238.28 & 0.0001 & $\mathrm{C}^{2}$ & -2.48 & 0.0001 & $\mathrm{C}^{2}$ & -6.09 & 0.0136 \\
\hline $\mathrm{D}^{2}$ & -774.59 & 0.0042 & $\mathrm{D}^{2}$ & -1.55 & 0.0043 & $\mathrm{D}^{2}$ & -5.13 & 0.0314 \\
\hline \multicolumn{3}{|c|}{ Others Statistics $\mathrm{R}^{2}=0.9041$} & \multicolumn{3}{|c|}{ Others Statistics $\mathrm{R}^{2}=0.9041$} & \multicolumn{3}{|c|}{ Others Statistics $\mathrm{R}^{2}=0.8502$} \\
\hline \multicolumn{3}{|c|}{ Sum of squares df } & \multicolumn{3}{|c|}{ Sum of squares $\mathrm{df}$} & \multicolumn{3}{|c|}{ Sum of squares df } \\
\hline Model & $2.916 \mathrm{E}+007$ & 14 & Model & 116.82 & 14 & Model & 1612.85 & 14 \\
\hline Residual & $3.093 \mathrm{E}+006$ & 12 & Residual & 12.41 & 12 & Residual & 284.07 & 12 \\
\hline Lack of fit & $3.093 \mathrm{E}+006$ & 10 & Lack of fit & 12.41 & 10 & Lack of fit & 284.07 & 10 \\
\hline Pure error & 0.000 & 2 & Pure error & 0.000 & 2 & Pure error & 0.00 & 2 \\
\hline F-value of model & 8.08 & - & F-value of model & 8.07 & - & F-value of model & 4.87 & - \\
\hline Correlation Total & $3.225 \mathrm{E}+007$ & 26 & Correlation Total & 129.22 & 26 & Correlation Total & 1896.92 & 26 \\
\hline
\end{tabular}

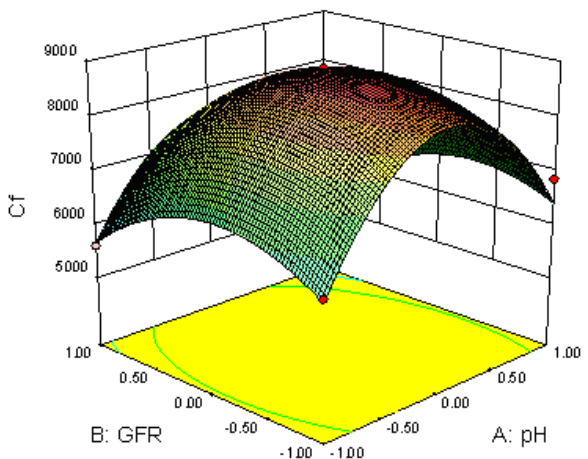

Figure 3. Three dimensional surface effect of $\mathrm{A}(\mathrm{pH})$ and $\mathrm{B}(\mathrm{GFR})$ on the response variables $\mathrm{Y} 1$ (Cf).

Quadratic model equations obtained by response surface methodology.

$\mathrm{Y}_{1}=8872.94-34.06 \mathrm{~A}-410.06 \mathrm{~B}+165.18 \mathrm{C}-119.47 \mathrm{D}-$ $181.95 \mathrm{AB}+256.07 \mathrm{AC}-224.87 \mathrm{AD}-84.55 \mathrm{BC}-200.11 \mathrm{BD}-$ 166.71CD $-2120.26 A^{2}-896.65 B^{2}-1238.28 C^{2}-774.59 D^{2}$

$\mathrm{Y}_{2}=17.74-0.63 \mathrm{~A}-0.83 \mathrm{~B}+0.32 \mathrm{C}-0.24 \mathrm{D}-0.37 \mathrm{AB}+0.52 \mathrm{AC}-$ $0.45 \mathrm{AD}-0.17 \mathrm{BC}-0.4 \mathrm{BD}-0.33 \mathrm{CD}-4.24 \mathrm{~A}^{2}-1.79 \mathrm{~B}^{2}-2.48 \mathrm{C}^{2}-$ $1.55 \mathrm{D}^{2}$

$\mathrm{Y}_{3}=94.27-0.18 \mathrm{~A}+0.68 \mathrm{~B}+2.51 \mathrm{C}-0.33 \mathrm{D}+3.31 \mathrm{AB}+1.75 \mathrm{AC}-$ $2.73 \mathrm{AD}-0.018 \mathrm{BC}-2.40 \mathrm{BD}-1.99 \mathrm{CD}-16.19 \mathrm{~A}^{2}-4.73 \mathrm{~B}^{2}-6.09$ $\mathrm{C}^{2}-5.13 \mathrm{D}^{2}$.

\subsection{Enrichment of protein in foamate}

$\mathrm{Y}_{2}=17.74-0.63 \mathrm{~A}-0.83 \mathrm{~B}+0.32 \mathrm{C}-0.24 \mathrm{D}-0.37 \mathrm{AB}+0.52 \mathrm{AC}-$ $0.45 \mathrm{AD}-0.17 \mathrm{BC}-0.4 \mathrm{BD}-0.33 \mathrm{CD}-4.24 \mathrm{~A}^{2}-1.79 \mathrm{~B}^{2}-2.48 \mathrm{C}^{2}-$ $1.55 \mathrm{D}^{2}$

After sequential elimination of the non-significant parameters $(p>0.05)$ from Table 4 , the above equation suitably described $\mathrm{Er}_{\mathrm{r}}$. Er values determined in the present study ranged between 10.23 and 17.85. The model had correlation coefficient $\left(\mathrm{R}^{2}\right)$ of 0.9040 that indicated only $3.61 \%$ could not be explained by the model. Model was significant with F-value of 8.47 ( $p=0.0004<0.05$ ). With the increased of gas flow rate both $A$ and $B$ showed increasing effect on $\mathrm{E}_{\mathrm{r}}$, though effect of $\mathrm{pH}$
(A) on separation of protein was found maximum at $\mathrm{pH}=5$ in comparison to $\mathrm{pH}=2$ and 8 . $\mathrm{E}_{\mathrm{r}}$ increased in the order of $\mathrm{pH} 5>$ $2>8$. Proteins adsorb more at the interface at $\mathrm{pH}=5$. This fact is supported by the strong negative regression coefficient of both $B$ and $B^{2}$. Effect of GFR on $Y_{2}$ is quadratic and it is showed negative regression coefficient indicating that highest $\mathrm{E}_{\mathrm{r}}$ can be obtained at the centre value of GFR. In this model only one interaction $(\mathrm{AB})$ had been found. The effect of $\mathrm{pH}$ and GFR at fixed $\mathrm{Ci}(500 \mathrm{mcg} / \mathrm{mL})$ was further revealed both from contour plot (Figure 4) and surface plot (Figure 5), enrichment ratio was maximum near centre values of both $\mathrm{pH}$ and GFR. Though $\mathrm{Y}_{2}$ is composed of primary response $\left(\mathrm{C}_{\mathrm{f}}\right)$ but the effects of factors on $Y_{2}$ were totally different from $Y_{1}$.

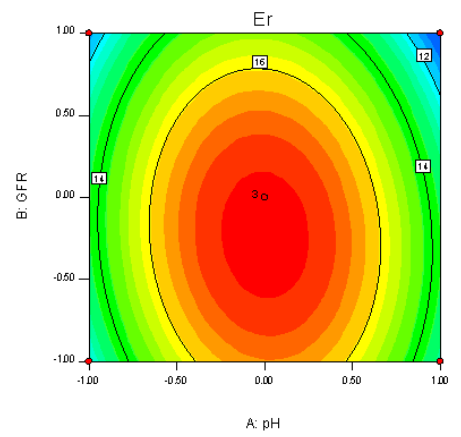

Figure 4. Two dimensional isoresponse curve of Enrichment (Er).

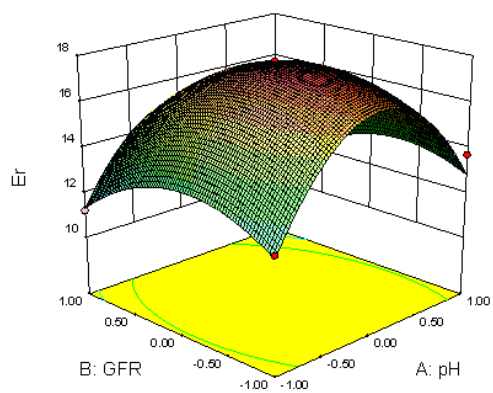

Figure 5. Three dimensional surface effect of $A(p H)$ and $B(G F R)$ on the response variablers Y2 (Er). 
Table 5. Percent relative error between experimental and predicted values as obtained from design solution*.

\begin{tabular}{|c|c|c|c|c|c|c|c|c|c|c|c|c|}
\hline \multicolumn{4}{|c|}{ Operating conditions } & \multicolumn{3}{|l|}{ Cf } & \multicolumn{3}{|l|}{ Er } & \multicolumn{3}{|l|}{$\%$ Rp } \\
\hline $\overrightarrow{\mathrm{pH}}$ & GFR & PSR & VFR & Pred. & Exp. & $\% \mathrm{RE}$ & Pred. & Exp. & \%RE & Pred. & Exp. & $\% \mathrm{RE}$ \\
\hline 0.00 & 1.00 & 0.00 & -1.00 & 7111.18 & 7110.02 & 0.016 & 14.21 & 13.00 & 2.24 & 87.81 & 86.80 & 1.159 \\
\hline 0.00 & -1.00 & 0.00 & 1.00 & 7692.45 & 7694.45 & -0.050 & 15.38 & 15.03 & 2.31 & 85.79 & 84.80 & 1.165 \\
\hline 0.00 & 0.00 & 0.00 & 0.00 & 8872.94 & 8871.92 & 0.011 & 17.74 & 17.20 & 3.04 & 94.27 & 93.59 & 0.721 \\
\hline 0.40 & -0.05 & 0.33 & -0.86 & 8139.41 & 8138.00 & 0.017 & 16.27 & 15.29 & 6.04 & 89.75 & 88.50 & 1.401 \\
\hline 0.30 & 0.07 & -0.77 & 0.31 & 7616.99 & 7618.00 & -0.013 & 15.22 & 14.26 & 6.36 & 86.45 & 87.50 & -1.21 \\
\hline-0.19 & -0.30 & -0.31 & -0.37 & 8549.96 & 8550.60 & -0.007 & 17.09 & 16.0 & 6.40 & 90.74 & 91.75 & -1.10 \\
\hline 0.29 & -0.43 & -.051 & 0.17 & 835.69 & 838.50 & -0.034 & 16.46 & 15.49 & 5.92 & 88.19 & 85.50 & 3.05 \\
\hline-0.37 & -0.82 & -0.76 & 0.55 & 7349.97 & 7347.50 & 0.033 & 14.69 & 15.50 & -0.37 & 85.14 & 89.50 & -5.11 \\
\hline
\end{tabular}

* Exp = Experimental Value, Pred = Predicted value, \%RE= Percentage Relative Error [i.e. (Pred-Exp)/Pred].

\subsection{Concentration of protein on percentage recovery}

$\mathrm{Y}_{3}=94.27-0.18 \mathrm{~A}+0.68 \mathrm{~B}+2.51 \mathrm{C}-0.33 \mathrm{D}+3.31 \mathrm{AB}+1.75 \mathrm{AC}-$ $2.73 \mathrm{AD}-0.018 \mathrm{BC}-2.40 \mathrm{BD}-1.99 \mathrm{CD}-16.19 \mathrm{~A}^{2}-4.73 \mathrm{~B}^{2}-6.09$ $C^{2}-5.13 D^{2}$

In the above model $\mathrm{Y}_{3}$ represents percent recovery of protein from whey waste feed by the foam fractionation method. $Y_{3}(\% \mathrm{Rp})$ was best described by the regression equation which was obtained after sequential omission of the non-significant terms ( $p>0.05$, Table 4$)$. The model could explain $79.99 \%$ of the behavior of \%Rp. F-value (4.87) proved the model was significant. Experimental values of $\% \mathrm{Rp}$ ranged between 65.41 and 89.94. Like other models $\left(\mathrm{Y}_{1}, \mathrm{Y}_{2}\right)$, the model showed positive value of regression coefficient of $\mathrm{C}$. Effect of quadratic terms $\left(\mathrm{A}^{2}, \mathrm{~B}^{2}\right)$ explained the enhancement of \%Rp up to the optimum, beyond which it decreased. There was only one interaction term (AC), which had negative regression coefficient that implies prominent effect of $A$. The 2-dimensional contour plot (Figure 6) and 3-dimensional surface plot (Figure 7) explained that $\% \mathrm{Rp}$ increased up to optimum value beyond which it declined with the increase of two vital parameters $\mathrm{C}_{\mathrm{i}}, \mathrm{pH}$ at fixed GFR. Maximum $\% \mathrm{R}_{\mathrm{p}}$ $(89.94 \%)$ was noticed at $\mathrm{pH} 5$ and $\mathrm{C}_{\mathrm{i}}, 0.5 \mathrm{mg} / \mathrm{mL}$.

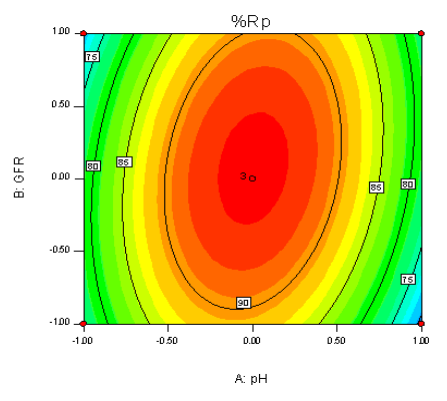

Figure 6. Two dimensional isoresponse curve of Percentage recovery (\% Rp).

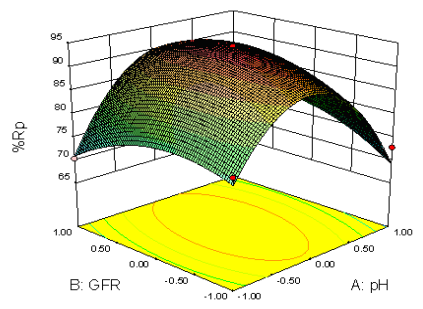

Figure 7. Three dimensional surface effect of A (GFR) and B (pH) on the response variablers Y3 (\%Rp).

\subsection{Optimization of the operating variables in foam fractionation experiment}

Software generated number of solutions from which several were picked up. Response variables from solution were presented as predicted variables were used and foam fractionating experiment was run again. The experimental response variables were compared with the predicted values and relative percent error was presented in Table 5 [23]. There was very less deviation from the predicted values. The present work gave satisfactory result at laboratory scale foam fractionation of whey in continuous mode. Thus, the optimized values of $\mathrm{C}_{\mathrm{f}}, \mathrm{E}_{\mathrm{r}}$ and $\% \mathrm{R}_{\mathrm{p}}$ were found $5143.14-8872.94 \mathrm{mcg} / \mathrm{mL}$, 10.23-17.74 and 65.46-94.27, respectively.

\section{Conclusion}

Optimization of foam fractionation of proteins from whey in continuous mode had been successfully performed using Box- Behnken method of RSM. Operating variables were modeled and expressed in terms of leveled factors. It reduces number of experiments to a minimum fractionation at restricted level of $\mathrm{C}_{\mathrm{i}}$.

\section{Acknowledgements}

The authors acknowledge to Bengal Chemists and Druggists Association College of Pharmacy and Technology, Kolkata, India, Jadavpur University, Kolkata, India and Hanseo University, Korea, for their cooperation to make the experiment success.

\section{References}

[1]. Hall, W. L.; Millward, D. J.; Long, S. J.; Morgan, L. M. Brit. J. Nutr. 2003 89, 239-248

[2]. Pearce, R. J. Food. Ress. Quartly. 1991, 51, 74-85.

[3]. De Wit, J. N. J. Dairy. Sci. 1998, 81, 597-608.

[4]. Pearce, R. J. U. S. Patent. 1995, 5, 331-340.

[5]. Fuda, E.; Bhatia, D.; Pyle, D. L.; Jauregi, P. Biotech. Bioeng. 2005, 90 531-542.

[6]. Hossain, Md. M.; Saleh, Z. Aust. Biotech. 2001, 11, 29-31.

[7]. Brown, A. K.; Kaul, A.; Varley, J. Biotech Bioeng., 1999, 62, 291-299.

[8]. Mass, K. Adsorptive Bubble Separation Technique, Academic Press, New York, 1974, 165-167.

[9]. Uraizee, F.; Nrsimhan, G. Engyme. Microb. Technol. 1990, 12, 315-316.

[10]. Lemlich, R. Adsorptive Bubble Separation Technique, Academic Press, New York, 1972, 133-143.

[11]. Maruyama, H.; Suzuki, A.; Inoue, N. Biochem. Engin. 2006, 30, 253259.

[12]. Suzuki, A.; Yasuhara, K.; Seki, H.; Maruyama, H. J. Colloid and Interface Sci. 2002, 253, 402-408.

[13]. Guerrero, S.; Alzamora, S. M.; Gerschenson, L. N. J. Food. Eng. 1996, 28 307-322.

[14]. Collar, C.; Martinez, C. S. J. Food. Sci. 1993, 58, 1324-1328.

[15]. De la Maza, A.; Marich, A. M.; Coderch, L.; Baucells, J.; Parra, J. L. Colloids Surfaces A 1996, 113, 259-267.

[16]. Shaoo, B. K.; Gowda, V.; Ghosh, A.; Chatterjee, B.; Bose, A.; Chakraborty, U.; Das, A.; Pal, T. K. Pharm. Ind. 2009, 71, 1423-1428.

[17]. Boea, A.; Leueuta, S. E. Drug Dev. Ind. Pharm. 1998, 24, 145-155.

[18]. Fuda, E.; Jauregi, P.; Pyle, D. L. J. Collod. Int. Sci. 2004, 20, 514-525.

[19]. Brown, A. K.; Kaul, A.; Varley, J. Biotech Bioeng. 1999, 62, 278-290.

[20]. Saleh, Z. S.; Hossain, Md. M. Chem. Eng. Process. 2001, 40, 371-378.

[21]. Du, L.; Prokop, A.; Tanner, R. D. Appl. Biochem. Biotech. 2002, 98-100, 1075-1091.

[22]. Ekici, P.; Backleh-Sohrt, M.; Parlar, H. J. Food. Sci. Nutria. 2005, 56, 223-229.

[23]. Ranghavan, C. V.; Babu, R. S.; Chand, N.; Rao, P. N. S. J. Food. Sci. Tech. 1996, 33, 313-321. 